\title{
FUNGICIDAL METHYL-2-BENZIMIDAZOLE CARBAMATE ADSORPTION IN SOIL AND REMEDIATION VIA Prunus dulcis DERIVED ACTIVATED CARBON
}

\author{
Adsorción en el suelo del fungicida metil-2-benzimidazol carbamato y
} remediación por carbón activado proveniente de Prunus dulcis

Khuram Shahzad AHMAD

Department of Environmental Sciences, Fatima Jinnah Women University, The Mall, 46000, Rawalpindi, Pakistan Email: chemist.phd33@yahoo.com,dr.k.s.ahmad@fjwu.edu.pk

(Received: February 2019; accepted: September 2019)

Key words: carbendazim, activation, precursor, soil pollution, sorption, organic matter

\begin{abstract}
Carbendazim (methyl-2-benzimidazole carbamate i.e. MBC) was investigated for pedospheric adsorption-desorption, mobility and effective removal via Prunus dulcis derived activated carbon in addition to physical and chemical characterization of selected soils. MBC was adsorbed into six agriculturally soils with distinctive characteristics via batch-equilibrium method and was evaluated via linear and Freundlich models. The highest value for linear and Freundlich adsorption coefficients i.e. $\mathrm{K}_{\mathrm{d}}$ and $\mathrm{K}_{\mathrm{f}}(8.8 \mu \mathrm{g} / \mathrm{mL}$ and $11 \mu \mathrm{g} / \mathrm{mL}$ respectively) corresponds to soil sample 6 having organic matter (3.3\%) and clay (18\%). Soils exhibited variable affinity towards MBC adsorption with $\mathrm{K}_{\mathrm{d}}$ ranging between 6.3 to $11 \mu \mathrm{g} / \mathrm{mL}$ and $\mathrm{K}_{\mathrm{f}}$ ranging from 5.2 to $7.4 \mu \mathrm{g} / \mathrm{mL}$, signifying weak adsorption of MBC in selected soils. Desorption for soil sample 1 was highest because all parameters favor the quicker MBC molecules detachment from soil particles deficient in organic matter. Results for current investigation were examined for statistical significance via one way analysis of variance goodness of fit determined with residual plots in Minitab. In the remediation assay, Prunus dulcis shells were used as precursors for activated carbon preparation. MBC was removed up to $100 \%$ in the lowest concentration, i.e. $2.5 \mathrm{ppm}$, while only $23 \%$ of MBC was removed in case of $7.5 \mathrm{ppm}$, expressing the concentration dependency of the remediation assay. Prunus dulcis shells derived activated carbon is a sustainable and non-toxic material, which opens the future arenas for further research on its commercialization potential for remediation of soil compartment.
\end{abstract}

Palabras clave: carbendazim, activación, precursor, contaminación del suelo, adsorción, materia orgánica

\section{RESUMEN}

Se investigó la adsorción-desadsorción, la movilidad y la remoción efectiva pedosférica del carbendazim (metil2-benzimidazol carbamato, MBC, por sus siglas en inglés) vía carbón activado obtenido de Prunus dulcis, además, se realizó la caracterización física y química de suelos seleccionados. El MBC se adsorbió en seis suelos agrícolas con características distintivas por medio del método del equilibrio en lotes que fue evaluado con los modelos lineal y de Freundlich. El valor más alto de los para los coeficientes de adsorción $\mathrm{K}_{\mathrm{d}}$ y $\mathrm{K}_{\mathrm{f}}$ de los modelos (lineal y de Freundlich), fue de $8.8 \mu \mathrm{g} / \mathrm{mL}$ y $11 \mu \mathrm{g} / \mathrm{mL}$, 
respectivamente, que corresponden a la muestra de suelo 6 con $3.3 \%$ de materia orgánica y $18 \%$ de arcillas. Los suelos exhibieron una afinidad de adsorción variable hacia el $\mathrm{MBC}$ con $\mathrm{K}_{\mathrm{d}}$ entre 6.3 y $11 \mu \mathrm{g} / \mathrm{mL}$ y $\mathrm{K}_{\mathrm{f}}$ de 5.2 a $7.4 \mu \mathrm{g} / \mathrm{mL}$, lo que representa una adsorción débil del MBC en los suelos seleccionados. La desadsorción en la muestra de suelo 1 fue mayor porque todos los parámetros favorecieron el rápido desprendimiento de las moléculas de las partículas del suelo deficiente en materia orgánica. Los resultados de la presente investigación se evaluaron para significación estadística por medio de la prueba de bondad de ajuste del análisis de varianza de una vía determinada por gráficas de residuos con Minitab. Para la prueba de remediación se utilizaron cáscaras de Prunus dulcis como precursoras del carbón activado. El MBC fue removido en un $100 \%$ en la concentración menor, 2.5 ppm, mientras que en la de 7.5 ppm sólo se removió el $23 \%$, demostrando la dependencia de la concentración en la prueba de remediación. El carbón activado obtenido de cáscaras de Prunus dulcis es un material sustentable no tóxico que abre opciones futuras de investigación sobre su potencial comercialización y como agente de remediación del suelo.

\section{INTRODUCTION}

Modern agriculture has been known for production of good quality crops, higher yields and crop protection against the vicious attacks of pests. Good quality crops and higher yields can only be ensured if crops are protected against pests, either through biological and physical means or through application of synthetic pesticides (Iftikhar et al. 2018). In this regard, the use of synthetic organic pesticides has been elevated since Green Revolution. Pest control has been ensured via excessive use of pesticides by farmers (Ali et al. 2013). Pesticide molecules possess an inherent toxicity towards the target species by bringing about a disruptive process. Active ingredients in pesticides augment their toxicity (Coupe and Capel 2015). Nevertheless, the use of pesticides in larger quantities has also affected the environment and induced negative transformations that might be a challenging task to restore. Thus, investigations comprising pesticide fate and remediation to reduce their mobility and consequent groundwater pollution. Though different physical, biological and chemical modes have been devised for reducing the transfer of toxic pesticide molecules and residues, prior to such treatment measures, complete investigation of fate is mandatory. Adsorption-desorption has been investigated for number of pesticides including herbicides, fungicides, insecticides etc., and all results were suggestive of the fact that greater organic matter laid soils prevent the transfer of pesticides to lower soil profiles or groundwater (Ahmad 2017a; Ahmad 2017b; Fenner et al. 2013; Ahmad et al. 2013). Furthermore, the sorption process is also known for impacting the pesticides' persistence in soils and its biological effectiveness.
Pesticide application in an area is consequently followed by either volatilization into the air or the picked up by plants. It can also percolate to the pedospheric compartment and convert into the ionized form. Such ionized products are known for reacting with water molecules and lead to the formation of oxides intermixing with the soils and alter the fertility extent. Pesticide adsorption can range from lower to higher in different types of soils depending upon various factors, e.g. some soils may poorly adsorb the pesticides (Ahmad et al. 2013) while others may express more affinity (Paszko 2014). Such an altering behavior of different soils towards one type of pesticide can be attributed to the spontaneous nature of the adsorption process taking place in nature and involved in pollution. Such an influence has instigated different researchers to investigate the adsorption process in simulated conditions at laboratory scale so that sustainable ways can be developed for the protection of soils and groundwater resources. The remaining pesticide molecules in soils, particularly in the top layer are abundantly available to the lithospheric biota. However, the adsorption interactions between soils and pesticides are dependent upon the partitioning extent between soil solution and the liquid phase. Results are in favor of alterations in adsorption with the passage of time. Thus, investigation about the kinetics of adsorption, time dependency and sorption aging have emerged as a new field in soil sciences.

Benzimidazole based fungicide, methyl-2-benzimidazole carbamate, commonly known as carbendazim (MBC) is a metabolite of benomyl. It has been widely used against a variety of fungi causing harm to crops, particularly fruits and cereals (Table I). MBC has been used initially in Europe in 1974 for the control of eyespot fungal disease in crops. 
MBC has a characteristic mode of action because it is dissolved in water leading to the formation of methyl benzimidazole carbonate. MBC interferes with the cellular division, and consequently causes the inhibition of those fungal hyphal growth which obtain their nourishment from crops (Roy 2002) e.g. Albugo candida, Plasmodiophora brassicae, Sclerotium rolfsii, Microdochium panattonianum, Puccinia sorghi, Puccinia allii etc. MBC has been known for its stability in natural ecological niches and its difficulty in degrading (Paszko 2014) in contrast to various other pesticides, which are effectively degraded by soil microbes (Gul and Ahmad 2017). Such high stability and resistance towards degradation is due to the presence of the benzimidazolic ring, enhancing its persistence in the soil environment. Ecological integrity seems to be at stake in such circumstances, where no investigations have been done for the presence of MBC residues in water or soils (Guo et al. 2011). $\mathrm{MBC}$ is absorbed by the plants through various routes, e.g. leaves, seeds or roots (de la Hubera et al. 2000, Boudina et al. 2003). It has a half-life of 3 to 6 months in turf, 1 to 2 months in sediments of rivers in aerobic conditions and 25 months in anaerobic conditions (Silva et al. 2014). The occurrence of various immobilization processes in the lithospheric compartment are environmentally significant because they reduce the bioavailability of organic contaminants. $\mathrm{MBC}$ is also known to be degraded by microbial strains, e.g. Bacillus subtilis, Pseudomonas putida, Brevibacillus borstelensis, Streptomyces albogriseolus etc. (Salunkhe et al. 2014, Arya and Sharma 2016). MBC adsorption and

TABLE I. PHYSICAL AND CHEMICAL PROPERTIES OF FUNGICIDE METHYL-2-BENZIMIDAZOLE CARBAMATE (MBC)

$\begin{array}{lc}\text { Chemical structure } & \text { methyl } \mathrm{N}-(1 \mathrm{H}-\text { benzimidazol-2-yl }) \\ \text { carbamate } \\ \text { Molecular formula } \\ \text { IUPAC name }\end{array} \begin{aligned} & 191.19 \mathrm{~g} / \mathrm{mol} \\ & \text { Molar mass } \\ & \text { Melting point } \\ & \text { Solubility in water } \\ & \text { Density }\end{aligned}$

IUPAC $=$ The International Union of Pure and Applied Chemistry desorption processes taking place in soils cannot be considered depending upon one single factor, but are being played upon by not only the physical and chemical characteristics of soils, but also the inherent properties of MBC.

Pakistan is known for the high quality export of various food crops, vegetables and fruits, due to which its economic growth is completely dependent upon the agricultural sector. By the virtue of fertile soils, higher precipitation rates and an efficient canal system, Pakistan had made an eminent place in the global market, however the fact of the vulnerability of Pakistan's crops to pest attacks, especially fungal infections, cannot be neglected. Pakistan has been using a variety of fungicides for overcoming the losses caused due to fungal attacks and for controlling several diseases, e.g. spots on leaves, shot marks in the leaves, blights, blasts, necrotic lesions in the form of cankers, rotting of stem and root, dieback, blotch, curling in leaves, rusts, smuts, mildews etc. MBC has been used for controlling fungal infections since many decades. Despite such large-scale utilization of MBC and other benzimidazole fungicides, the studies reported to date are limited to an extent that evaluation of $\mathrm{MBC}$ fate in environmental compartments and the associated risks is not possible. In a country like Pakistan, where soils are deficient in organic matter and have comparatively lower $\mathrm{pH}$, the adsorption of $\mathrm{MBC}$ must be determined to know its fate. Lack of data in this regard motivated the present research, which has closely studied the chemistry between MBC and soils from six different regions of Pakistan via the batch equilibrium method, and its cost-effective removal by using activated carbon prepared from almond shells. The major objective of the study was the determination of the sorption behavior, consequent mobility pattern and effective removal, so that ground water resources and lower soil profiles can be protected in a sustainable way.

\section{EXPERIMENTAL}

\section{Precursor, materials and instrumentation}

Prunus dulcis shells as precursors for activated carbon were purchased from a local market in Rawalpindi Pakistan. Analytical standard carbendazim, methyl 1- H- benzimidazole-2-carboxylate (MBC), sodium chloride, calcium chloride and potassium bromide were purchased from ACCU Standard, USA, and were used without further 
purification. Analytical grade solvents, acetone and methanol used were $99.9 \%$ pure and were used in solution preparation and apparatus sterilization. A standard stock solution of MBC was prepared in distilled water (DW). Concentrated $\mathrm{H}_{2} \mathrm{SO}_{4}$ was used for activation of Prunus dulcis shells. Weighting balance (ATx224, Shimadzu company), weighting machine (AUX220, Shimadzu company), orbital incubator shaker (Irmeco Gmbh Germany), centrifuge (Sigma 26-E, Hettich Company), hot plate (MSH-20D, Wisestir instruments), atomic spectrophotometer (220, Varian company), UV-visible spectrophotometer (BMS-1602), octagonal sieve shaker (Endecotts company), pH meter (WTW Ino Labs company) and EC meter (Crison company) were used in the experiments.

\section{Adhesive media sampling and formulation}

Soils from six different regions were used like adhesive media for the MBC molecules to form a thin film (TF) and thin film detachment (TFD) from five provincial territories of Pakistan i.e. Ormara (Balochistan), central Gilgit (Gilgit Baltistan), Pasni (Balochistan), Mianwali and Sialkot (Punjab) and Swabi (Khyber Pakhtunkhwa) (Fig. 1). Sampling for adhesive media was done in May 2016 from regions where no pesticides have been applied, so that the behavior of MBC can be assessed. Samples were taken from the plough layer at depth of $0-6 \mathrm{~cm}$. These soils were shifted to clean polyethylene bags and tightly sealed and transferred to the laboratory for further formulations to be used in sorption and remediation assays. The soils were air dried for 48 hours in a greenhouse at ambient temperature, follow by thorough grinding with pestle and mortar.

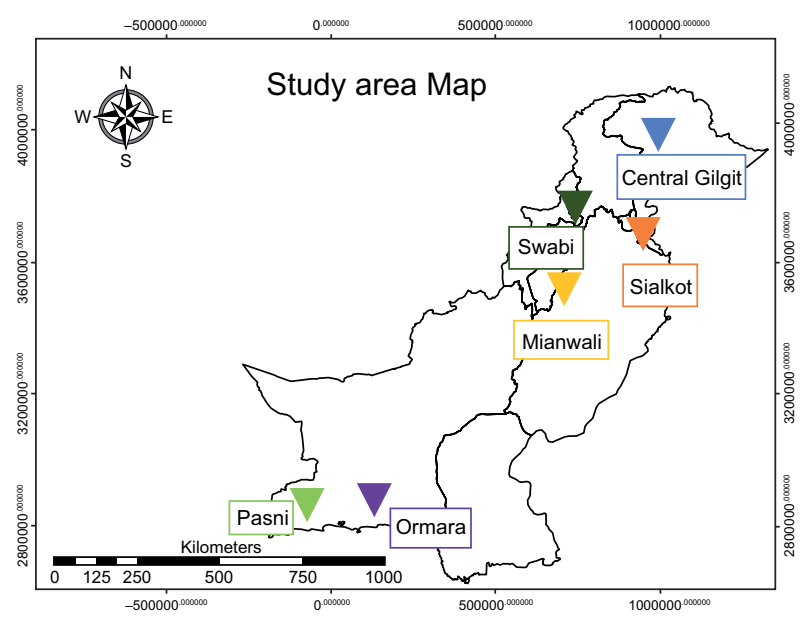

Fig. 1. Map of Pakistan displaying the sampling sites
Prepared samples were sieved with a $2 \mathrm{~mm}$ sieve individually and mixed thoroughly until homogeneous. Homogenized soil samples were then used for the determination of physical and chemical characteristics in addition to heavy metals determination (Table II). Samples were stored in sterilized bags for further processing.

\section{MBC-TF formation on adhesive media}

The specific batch equilibrium method for adsorption desorption of MBC in six selected soils, test guideline 106 given by the Organization for Economic Co-operation and Development (OECD), was followed. Adsorption and desorption experiments were performed at ambient temperature $\left(20-25^{\circ} \mathrm{C}\right)$. An MBC 10 ppm stock solution was prepared by dissolving $10.3 \mathrm{mg}$ of MBC in DW with a few drops of acetone and stirred for $24 \mathrm{~h}$ for ensuring the complete dissolution. This was followed by dilutions preparation from $\mathrm{MBC}$ stock solution, i.e. 0, 0.25, 0.5, 0.75, $1,2.5,5$ and $7.5 \mathrm{ppm}$ in $15 \mathrm{~mL}$ test tubes, filled with $0.1 \mathrm{M} \mathrm{NaCl}$ as background electrolyte for adjustment of ionic strength. Prepared samples aimed at MBC thin film formation on the targeted soils in addition to their duplicates and blanks were shaken for 48 $\mathrm{h}$ at $150 \mathrm{rpm}$ on a rotary shaker. Suspensions were centrifuged at $3500 \mathrm{rpm}$ for $10 \mathrm{~min}$. This step developed equilibrium between soil solutions and MBC. Absorbance after filtration using a $0.2 \mu \mathrm{m}$ membrane filter was spectrophotometrically determined with a UV-Visible spectrophotometer (BMS-1602). The clear aliquots were taken for the analysis.

\section{MBC-TF detachment on adhesive media}

Desorption experiment for assessing the detachment pattern of MBC thin film was done immediately after the adsorption experiment by decantation of the supernatant from the reaction vials. $9 \mathrm{~mL}$ of freshly prepared $\mathrm{CaCl}_{2}$ was poured into the decanted tubes in order to compensate for possible losses occurring during the reaction. Reactions tubes were shake on a rotary shaker for $48 \mathrm{~h}$ at $150 \mathrm{rpm}$ and centrifuged at $3500 \mathrm{rpm}$ for $10 \mathrm{~min}$, then filtered with a $0.2 \mu \mathrm{m}$ membrane filter and the clear aliquots were taken for the analysis.

\section{UV-Vis data usage and multilayer TFF and TFD}

UV-Vis data obtained for MBC TF formation and TF detachment was stored in form of absorbance and Lambda maximum on the program associated with UV-Vis (BMS-1602) in the range of 200-600 $\mathrm{nm}$. MBC concentration dependent data were then used for plotting the linear and Freundlich adsorption 
TABLE II. SET OF EQUATION FOR ANALYSIS OF CARBENDAZIM (MBC) SORPTION DATA IN SELECTED SOILS

\begin{tabular}{|c|c|c|}
\hline Eq. No & Equations for adsorption-desorption & Description \\
\hline 1 & $\mathrm{C}_{\mathrm{s}}=\mathrm{V} / \mathrm{m} \times\left(\mathrm{C}_{\mathrm{b}}-\mathrm{C}_{\mathrm{a}}\right)$ & $\begin{array}{l}C_{s}=\text { MBC concentration adsorbed } \\
V=\text { solution volumetric extent } \\
m=\text { selected soils quantity in } g \\
C_{a}=\text { equilibrium concentration of the supernatant } \\
C_{b}=\text { the equilibrium concentration of the blank }\end{array}$ \\
\hline 2 & $\mathrm{~K}_{\mathrm{d}}=\mathrm{C}_{\mathrm{s}} / \mathrm{C}_{\mathrm{e}}$ & $\begin{array}{l}\mathrm{K}_{\mathrm{d}}=\text { linear adsorption coefficient in } \mu \mathrm{g} / \mathrm{mL} \\
\mathrm{C}_{\mathrm{e}}=\text { concentration of the } \mathrm{MBC} \text { at equilibrium in } \mu \mathrm{g} / \mathrm{mL} \\
\mathrm{C}_{\mathrm{s}}=\text { concentration of } \mathrm{MBC} \text { adsorbed in } \mu \mathrm{g} / \mathrm{mL}\end{array}$ \\
\hline 3 & $\mathrm{~K}_{\mathrm{f}}=\mathrm{C}_{\mathrm{s}} / \mathrm{C}_{\mathrm{e}}$ & $\begin{array}{l}\mathrm{K}_{\mathrm{f}}=\text { Freundlich adsorption coefficient in } \mu \mathrm{g} / \mathrm{mL} \\
\mathrm{C}_{\mathrm{e}}=\text { concentration of the } \mathrm{MBC} \text { at equilibrium in } \mu \mathrm{g} / \mathrm{mL} \\
\mathrm{Cs}=\text { concentration of } \mathrm{MBC} \text { adsorbed in } \mu \mathrm{g} / \mathrm{mL}\end{array}$ \\
\hline 4 & $C=k_{f} \cdot C_{e} 1 / \mathrm{n}$ & $\begin{array}{l}1 / \mathrm{n}=\text { Freundlich constant obtained by using the Freundlich equation in linear } \\
\text { form }\end{array}$ \\
\hline 5 & $K_{o c}=K_{d} / \% C \cdot 100$ & $\begin{array}{l}\mathrm{K}_{\mathrm{oc}} \text { determination is necessary for mobility determination. The values of } \mathrm{K}_{\mathrm{oc}} \text { were } \\
\text { checked according to McCall classification and mobility extents were predicted }\end{array}$ \\
\hline 6 & $K_{f o c}=K_{f} / \% C \cdot 100$ & $\begin{array}{l}\text { Similar to } \mathrm{K}_{\mathrm{oc}}, \mathrm{K}_{\mathrm{foc}} \text { determines the MBC affinity for thin film formation on } \\
\text { selected soils }\end{array}$ \\
\hline 7 & $K_{O M}=K_{d} / \% O M \cdot 100$ & $\begin{array}{l}\text { Coefficient for organic matter determination in relation to Freundlich adsorption } \\
\text { coefficient }\end{array}$ \\
\hline 8 & $\log C_{s}=\log K_{f}+1 / n \log _{e}$ & $\begin{array}{l}\mathrm{K}_{\mathrm{f}} \text { is Freundlich adsorption coefficient, } 1 / \mathrm{n} \text { is Slope of Freundlich adsorption iso- } \\
\text { therm, } \mathrm{n} \text { is a linearity factor, also known as adsorption intensity and } \log \mathrm{K}_{\mathrm{f}} \text { is the } \\
\text { intercept of the straight line resulting from the plot of } \log \mathrm{C}_{\mathrm{s}} \text { versus } \log \mathrm{C}_{\mathrm{e}} \text { while } \\
\mathrm{C}_{\mathrm{s}} \text { and } \mathrm{C}_{\mathrm{e}} \text { are defined previously }\end{array}$ \\
\hline 9 & $\Delta \mathrm{G}=-\mathrm{RTLnK} \mathrm{K}_{\mathrm{Om}}$ & $\begin{array}{l}\mathrm{R}=\text { universal gas constant } \\
\mathrm{T}=\text { temperature in Kelvin } \\
\mathrm{Ln}=\mathrm{Log} \text { natural }\end{array}$ \\
\hline 10 & $\mathrm{H}=\mathrm{n}_{\mathrm{ads}} / \mathrm{n}_{\text {des }}$ & $\mathrm{n}_{\text {ads }}$ and $\mathrm{n}_{\text {des }}$ ratio for Freundlich adsorption and desorption constants \\
\hline
\end{tabular}

isotherms for investigating the multilayer adsorptiondesorption of $\mathrm{MBC}$ on selected soils through different coefficients, e.g. $K_{d}, K_{o c}, K_{f}, K_{\text {foc }}$ etc. Calculations for adsorption and desorption data were performed following the equations of table II.

\section{MBC-TF remediation via Prunus dulcis shells precursors \\ Prunus dulcis shells driven activated carbon for- mulation}

The purchased Prunus dulcis shells were washed for removing any dust particles and dried in open air for $48 \mathrm{~h}$ followed by oven drying at $100{ }^{\circ} \mathrm{C}$ for 4 $\mathrm{h}$. The second phase oven drying was done for the complete removal of any possible volatile impurities present in the Prunus dulcis shells. Completely dried shells were ground into a fine powder with an electrical grinder and stored in a glass bottle for further working. Concentrated $\mathrm{H}_{2} \mathrm{SO}_{4}$ was added to around
$500 \mathrm{~g}$ of the ground powder for the achievement of the 1:1 impregnation ratio. Concentrated $\mathrm{H}_{2} \mathrm{SO}_{4}$ quantity was exactly equal to the quantity of Prunus dulcis shell powder. Concentrated $\mathrm{H}_{2} \mathrm{SO}_{4}$ was used for Prunus dulcis shell activation for quicker thermal disintegration in a single step reaction. Prunus dulcis shells derived activated carbon can be reused again after washing it thoroughly with ethanol. Slurry containing Prunus dulcis shell powder and concentrated $\mathrm{H}_{2} \mathrm{SO}_{4}$ were mixed and kept in the fume hood for achieving maximum soaking. This was followed by washing with cold DW so that unrequired acid can be removed. Obtained activated carbon was further treated with $5 \%$ sodium bicarbonate solution for $24 \mathrm{~h}$ and washed with water until attainment of neutral $\mathrm{pH}$. The prepared Prunus dulcis shell derived activated carbon (PD-AC) was ground to fine powder, heated at $110{ }^{\circ} \mathrm{C}$ for $24 \mathrm{~h}$ and stored in tightly capped containers for further use. 
$P D-A C$ remediation assay for $M B C$

MBC contamination in soils was remediated by PD-AC in a simple method by preparation of three dilutions from $\mathrm{MBC}$ stock solution, i.e. 2.5, 5 and $7.5 \mathrm{ppm}$. In a particular assemblage, $0.5 \mathrm{~g}$ of soil was weighed and placed in a $15 \mathrm{~mL}$ centrifuge tube. It was then mixed with $10 \mathrm{~mL}$ of MBC stock solution from each dilution and the absorbance for all three dilutions was obtained via the UV-Vis spectrophotometer (BMS-1602). Following the UV-Vis reading for the soil and MBC stock solution dilutions, $0.5 \mathrm{~g}$ of PD-AC were added to each tube. The prepared tubes were shaken for $1 \mathrm{~h}$ at $150 \mathrm{rpm}$ for increasing contact time between $\mathrm{PD}-\mathrm{AC}$ and the adhesive media containing the TF of MBC in them. The same procedure was repeated for another assemblage by varying the time for $3 \mathrm{~h}$. In the final step, the percent removal of $\mathrm{MBC}$ from the adhesive media, i.e. soils, was compared (Ahmad 2018).

\section{RESULTS AND DISCUSSION}

The lack of data available for MBC fate determination in selected soils with agricultural significance gave rise to the current research. This investigation has explored the benzimidazole based fungicide MBC adsorption-desorption process and its removal via prepared almond shells through activation with concentrated $\mathrm{H}_{2} \mathrm{SO}_{4}$, in addition to the physical and chemical characterization of selected soils which acted as the adhesive media for deposition of MBC thin film in a standard batch equilibrium method in simulated conditions. Adsorption-desorption extent determination of $\mathrm{MBC}$ in the selected pedospheric media was essential because just like other agrochemicals, e.g. herbicides, insecticides, fertilizers etc., MBC volatilization, mobility, degradation and retention is also determined by its interaction with the soil particles in the in the presence of several forces such as the van der Waals forces. Adsorptive and desorptive processes expressed a large dependence on $\mathrm{pH}$, clay and soil organic matter (SOM) in the same pattern as for other benzimidazole fungicides, e.g. thiabendazole (Ahmad 2017c). Furthermore, a cost effective way was also adopted for MBC removal from the selected soils. Thus, the present research not only contributes to the surface chemistry between selected soils and MBC, but also plays a role in the minimization of the soil and water pollution by using an effective way for remediation.

\section{Adhesive media characterization}

Selected soils in the investigation expressed distinctive physical and chemical characteristics related to their spatial and climatic variability. As shown in table III, soils from different provincial regions expressed variable traits. The $\mathrm{pH}$ ranged between 6.6 to 8.6 for all soils, with the highest $\mathrm{pH}$ for soil sample 1 (Ormara, Balochistan). Alkaline $\mathrm{pH}$ range can either be attributed to the presence of parent material having higher calcareous composition or it can be a result of various processess, e.g. liming of soils by local farmers. The lowest $\mathrm{pH}$ range corresponds to soil sample 3 (Pasni), which is also located in the same provincial territory, but due to the closeness of sea shore, soils are rich in acidifying salt content, thus reducing the $\mathrm{pH}$ range. Selected soils also expressed variability in SOM ranging from 1.2 to $3.3 \%$. As Pakistani soils are not abundant in SOM as a whole, the presence of $3.3 \%$ in the soil sample 6 (Swabi, KPK) is suggestive of higher decomposition rates wither triggered by a large microbial community or by the virtue of climatic conditions. Furthermore, soils were also different from each other for textural characteristics.

TABLE III. PHYSICAL AND CHEMICAL PROPERTIES OF SELECTED SOILS ACTING AS AN ADHESIVE MEDIA FOR CARBENDAZIM MOLECULES ATTACHMENT AND DETACHMENT

\begin{tabular}{|c|c|c|c|c|c|c|c|c|c|c|c|c|c|c|c|}
\hline Soils & Location & $\mathrm{pH}$ & $\begin{array}{c}\mathrm{SOM} \\
\%\end{array}$ & $\begin{array}{c}\text { Total } \\
\text { nitrogen } \%\end{array}$ & $\begin{array}{c}\text { TOC } \\
\%\end{array}$ & $\begin{array}{c}\text { Sand } \\
\%\end{array}$ & $\begin{array}{c}\text { Silt } \\
\%\end{array}$ & $\begin{array}{c}\text { Clay } \\
\%\end{array}$ & $\begin{array}{c}\text { CEC } \\
\text { (Meq 100/g) }\end{array}$ & $\begin{array}{c}\mathrm{EC} \\
(\mu \mathrm{s} / \mathrm{cm})\end{array}$ & $\begin{array}{l}\mathrm{Pb} \\
\mathrm{ppm}\end{array}$ & $\begin{array}{l}\mathrm{Cd} \\
\mathrm{ppm}\end{array}$ & $\begin{array}{c}\mathrm{Ni} \\
\mathrm{ppm}\end{array}$ & $\begin{array}{l}\mathrm{Cu} \\
\mathrm{ppm}\end{array}$ & $\begin{array}{c}\mathrm{Zn} \\
\mathrm{ppm}\end{array}$ \\
\hline S1 & Ormara & 8.6 & 1.2 & 0.34 & 0.69 & 19 & 74 & 7 & 6.7 & 272 & 2.88 & 0.05 & 0.68 & 0.17 & 0.07 \\
\hline $\mathrm{S} 2$ & Gilgit & 7.0 & 1.6 & 0.39 & 0.93 & 54 & 38 & 8 & 7.0 & 201 & 1.15 & 0.09 & 0.73 & 0.13 & 0.30 \\
\hline S3 & Pasni & 6.6 & 1.8 & 0.31 & 1.04 & 50 & 33 & 17 & 7.8 & 84 & 3.31 & 1.20 & 0.73 & N.D & 0.08 \\
\hline S4 & Mianwali & 8.1 & 2.3 & 0.36 & 1.33 & 59 & 34 & 7 & 7.5 & 120 & 3.47 & 0.06 & 0.68 & N.D & 0.09 \\
\hline S5 & Sialkot & 8.0 & 2.8 & 0.08 & 1.62 & 57 & 31 & 12 & 7.1 & 189 & 1.43 & 0.11 & 0.69 & N.D & 0.16 \\
\hline S6 & Swabi & 7.3 & 3.3 & 0.09 & 1.91 & 34 & 48 & 18 & 7.4 & 232 & 0.72 & 0.15 & 0.43 & 0.04 & 0.08 \\
\hline
\end{tabular}

$* \mathrm{SOM}=$ soil organic matter, $\mathrm{TOC}=$ total organic carbon, $\mathrm{CEC}=$ cation exchange capacity, $\mathrm{EC}=$ electrical conductivity 
In terms of the current interest for the adsorptiondesorption process, soil sand content and soil clay content are of the prime significance. Soil sample 4 (Mianwali, Punjab) exceeded all soils in possessing higher sandy particles due to geographical attributes, while soil sample 6 (Swabi, KPK) was found to be rich in clay content among all tested soils. Heavy metals such as $\mathrm{Pb}, \mathrm{Cd}, \mathrm{Ni}, \mathrm{Cu}$ and $\mathrm{Zn}$ were also determined in the selected soils. High levels of heavy metals can be a source of toxicity not only for the crops grown in that region, but also for the soils, and may leach down to soil profiles and underground water storage bodies.

\section{MBC TF formation and detachment}

MBC thin film formation and detachment were analyzed via isotherm based MBC mass transfer. A division between different compartments in a typical sorption behavior was observed. $\mathrm{MBC}$ adsorption to the selected soils is nonlinear, confirmed via irreversible adsorption. Two models adopted for this analysis were the linear and Freundlich models. The linear adsorption model was obtained by plotting MBC equilibrium concentration $(\mu \mathrm{g} / \mathrm{mL})$ on the $\mathrm{X}$-axis and $\mathrm{MBC}$ adsorbed $(\mu \mathrm{g} / \mathrm{mL})$ on the $\mathrm{Y}$-axis. Various other parameters were derived (Table IV;

Table V).

\section{MBC adsorption magnitude}

MBC attachment to the selected soils was determined via $K_{d}$ values, which provided an insight to the level and adsorption potential of each soil. $\mathrm{K}_{\mathrm{d}}$ values ranged between 6.3 and $11 \mu \mathrm{g} / \mathrm{mL}$, with soil sample 1 expressing the lowest MBC adsorption and soil sample 6 adsorbing MBC in greater quantities (Fig. 2). Greater $K_{d}$ values signify stronger surface
TABLE V. LINEAR AND FREUNDLICH DESORPTION CHARACTERISTICS OF MBC IN SOILS

\begin{tabular}{ccccccc}
\hline Soils & $\begin{array}{c}\mathrm{K}_{\mathrm{d}(\mathrm{des})} \\
(\mu \mathrm{g} / \mathrm{mL})\end{array}$ & $\mathrm{R}^{2}$ & $\begin{array}{c}\mathrm{K}_{\mathrm{f}} \\
(\mu \mathrm{g} / \mathrm{mL})\end{array}$ & $\mathrm{R}^{2}$ & $\mathrm{n}_{\mathrm{d}}$ & $\mathrm{H}$ \\
\hline S1 & 7.4 & 0.82 & 6.0 & 0.99 & 1.7 & 0.6 \\
S2 & 6.7 & 0.98 & 5.7 & 0.91 & 1.6 & 0.7 \\
S3 & 5.2 & 0.99 & 3.8 & 0.92 & 0.9 & 0.5 \\
S4 & 5.6 & 0.89 & 4.8 & 0.89 & 1.2 & 0.6 \\
S5 & 6.3 & 0.99 & 6.8 & 0.79 & 0.8 & 0.3 \\
S6 & 6.5 & 0.99 & 6.6 & 0.83 & 0.9 & 0.5 \\
\hline
\end{tabular}

$* \mathrm{~K}_{\mathrm{d}(\mathrm{des})}=$ linear desorption coefficient, $\mathrm{K}_{\mathrm{f}}=$ Freundlich desorption coefficient, $\mathrm{n}_{\mathrm{d}}=$ Freundlich parameter for desorption, $\mathrm{H}=$ hysteresis

attachment of MBC molecules to the soils and makes a thin film over the surface, while the lower values correspond to insignificant attachment on the soil particles. MBC also expressed variable adsorption affinities towards the six types of soil and the results are consistent with other fungicides, e.g. strobilurin fungicides (Azarkan et al. 2016). In the adsorption extent characterization used in Test Guidelines for Environmental Safety Assessment for Chemical Pesticides (USEPA 2008) the $K_{d}$ values express the adsorption extent, i.e. there is greater difficulty in pesticide adsorption if $\mathrm{K}_{\mathrm{d}}<5$, comparatively less difficulty if $K_{d}$ is $5 \sim 20$ and finally pesticide adsorption will be of medium scale if $\mathrm{K}_{d}$ is between 20 50. The application of this criteria to the obtained results shows that the adsorption of $\mathrm{MBC}$ by the selected soils was not difficult, since the $\mathrm{K}_{\mathrm{d}}$ range was $6.3-11 \mu \mathrm{g} / \mathrm{mL}$, namely a type II adsorption level for all soils. A similar trend can also be observed for $\mathrm{K}_{\mathrm{f}}$ (Fig. 3).

TABLE IV. LINEAR AND FREUNDLICH ADSORPTION CHARACTERISTICS OF CARBENDAZIM IN SELECTED SOILS

\begin{tabular}{lllllllll}
\hline Soils & $\begin{array}{c}\mathrm{K}_{\mathrm{d}(\mathrm{ads})} \\
(\mu \mathrm{g} / \mathrm{mL})\end{array}$ & $\mathrm{R}^{2}$ & $\mathrm{~K}_{\mathrm{oc}}$ & $\begin{array}{c}\Delta \mathrm{G} \\
(\mathrm{Kj} / \mathrm{mol})\end{array}$ & $\begin{array}{c}\mathrm{K}_{\mathrm{f}} \\
(\mu \mathrm{g} / \mathrm{mL})\end{array}$ & $\mathrm{R}^{2}$ & $\mathrm{~K}_{\text {foc }}$ & $\mathrm{n}_{\mathrm{a}}$ \\
\hline S1 & 6.3 & 0.99 & 298.0 & -9.9 & 4.8 & 0.91 & 513 & 2.5 \\
S2 & 7.1 & 0.98 & 303.0 & -10 & 5.3 & 0.99 & 494 & 2.3 \\
S3 & 9.0 & 0.92 & 570.0 & -19 & 6.8 & 0.99 & 174 & 1.7 \\
S4 & 7.3 & 0.98 & 343.0 & -14 & 5.8 & 0.89 & 492 & 2.0 \\
S5 & 9.7 & 0.68 & 683.0 & -15 & 6.6 & 0.88 & 686 & 2.7 \\
S6 & 11 & 0.73 & 1007 & -15 & 8.8 & 0.92 & 821 & 1.7 \\
\hline
\end{tabular}

$* \mathrm{~K}_{\mathrm{d}(\mathrm{ads})}=$ linear adsorption coefficient, $\mathrm{K}_{\mathrm{oc}}=$ linear adsorption coefficient normalized for organic carbon, $\Delta \mathrm{G}=$ Gibbs free energy change, $\mathrm{K}_{\mathrm{f}}=$ Freundlich adsorption coefficient, $\mathrm{K}_{\text {foc }}=$ Freundlich adsorption coefficient normalized for organic carbon, $\mathrm{n}_{\mathrm{a}}=$ Freundlich parameter for adsorption. 

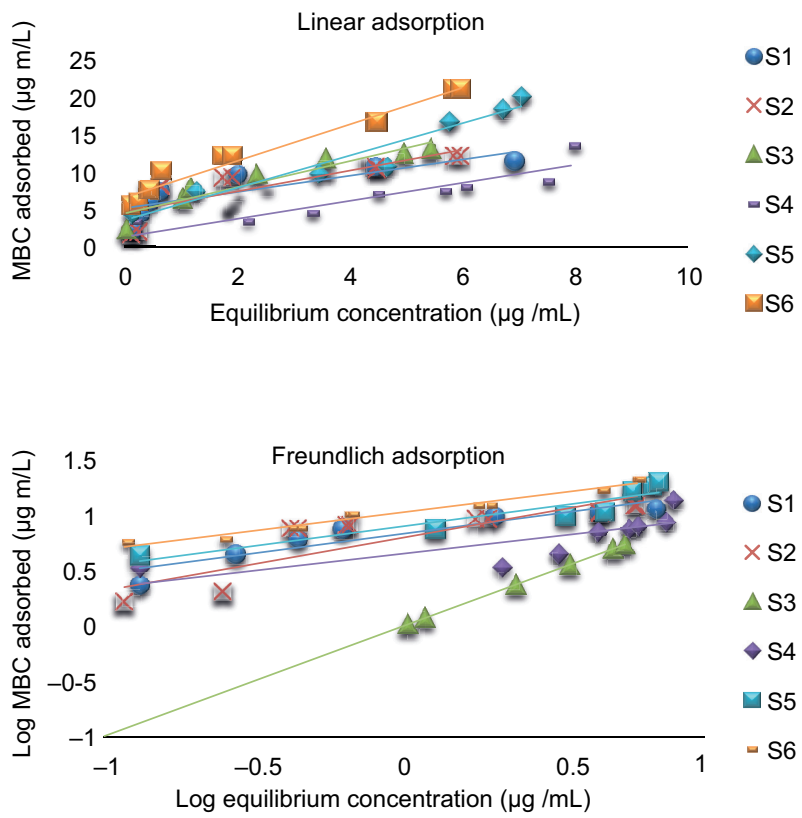

Fig. 2. Comparative graph showing the adsorption of carbendazim (MBC) in selected soils

\section{Reliance of MBC adsorption on soils' physical and chemical factors}

MBC adsorption variability checked via $K_{d}$ and $K_{f}$ can be comprehended in terms of the $\mathrm{MBC}$ variable response towards different soils for the formation of a thin film. The most significant factor in this regard is the SOM. SOM in the current investigation varied from 1.2 to $3.3 \%$. SOM provides different functional groups for the attachment of pesticide molecules such as carboxyl, phenyl, hydroxyl, carbonyl and methyl groups, among others. Thus, SOM act as an attachment media for MBC molecules via production of hydrogen bonds. Soil sample 6 is consistent with this fact. Results for other studies on azoxystrobin also confirm that its dissipation was faster in soils with lower organic matter content than the soils which were deliberately amended with organic content (Herrero-Hernández et al. 2015) MBC residence in soils is thus dependent upon the MBC properties, soils' physical, chemical and biological characteristics, soil organic amendments etc. MBC is water soluble, thus, there are chances of its leaching to groundwater resources as it did not express strong adsorption relationship with the soil particles or SOM, and prevented surface entrainment (Pose-Juan et al. 2015). In addition to the SOM, clay content of soils also influence adsorption extent. Pakistan has variable soil textures due to sharp difference between the weather pattern, climatic variability and parent rock material. In this finding, soil sample 6 having $18 \%$ clay content expressed greater adsorption. This can be attributed to the composition of soil sample 6, being the smectite family of clay minerals and consequently expressing greater retention of MBC. Furthermore, the layered sheet like structure of phyllosilicates has negative charges compensated by positive charges in the spaces of the interlayers. Such complicated layered morphologies not only provide a higher surface area for MBC molecules but also develop hydrogen bonding with it. In addition to SOM and clay content, soil $\mathrm{pH}$ also has great impact on the level of adsorption. Current results are suggestive of better adsorption in soils having lower $\mathrm{pH}$ and decreased adsorption in soils having higher $\mathrm{pH}$. Current results are consistent with other Benzimidazole fungicide, $\mathrm{s}$ e.g. thiabendazole (de Oliveira et al. 2017)

For other pesticides, e.g. atrazine, isoproturon and paraquat, results are also suggestive of little impact of dissolved organic matter on adsorption. Such behavior can be best comprehended by developing a correlation analysis between different parameters of soil and MBC adsorption. Such an approach will also enhance the understanding of soil clean up strategies (Liu et al. 2018). MBC molecules detachment from selected soils is dependent upon soils' physical and chemical characteristics (Pavlovic et al. 2018). Soil sample 1 expressed highest desorption potential for having the highest $\mathrm{pH}, 8.6$, and lowest organic matter, $1.2 \%$. Comparatively easier MBC TF detachment from soil sample 1 is suggestive of the ease leaching of the $\mathrm{MBC}$ molecules in its intact form or as converted daughter products towards the lower soil profiles and underground water reserves. Furthermore, these residues might be taken up by crops grown in the following season and might also be translocated to regions through volatilization, leaching, etc. In this research, it can be seen that $n_{a}$ value of soil 6 is lesser as compared to the remaining five soils. It indicates the intensity of adsorption. Similarly, the $\mathrm{n}_{\mathrm{d}}$ values are used to check the intensity of desorption occurring in the soil samples. In the present study desorption hysteresis coefficient, $\mathrm{H}$, in all six soils is found to be from 0.3 to 0.7 , which demonstrates that hysteresis is present. Although the occurrence of hysteresis indicates that the adsorption isotherms are slightly different from the desorption isotherms, the value of $\mathrm{H}$ close to 1 means that desorption process took place almost as quickly as adsorption did. The value of hysteresis is closer to 1 in soil 2 indicating that the soil have undergone the process of desorption almost as quickly as adsorption. This effect can be 

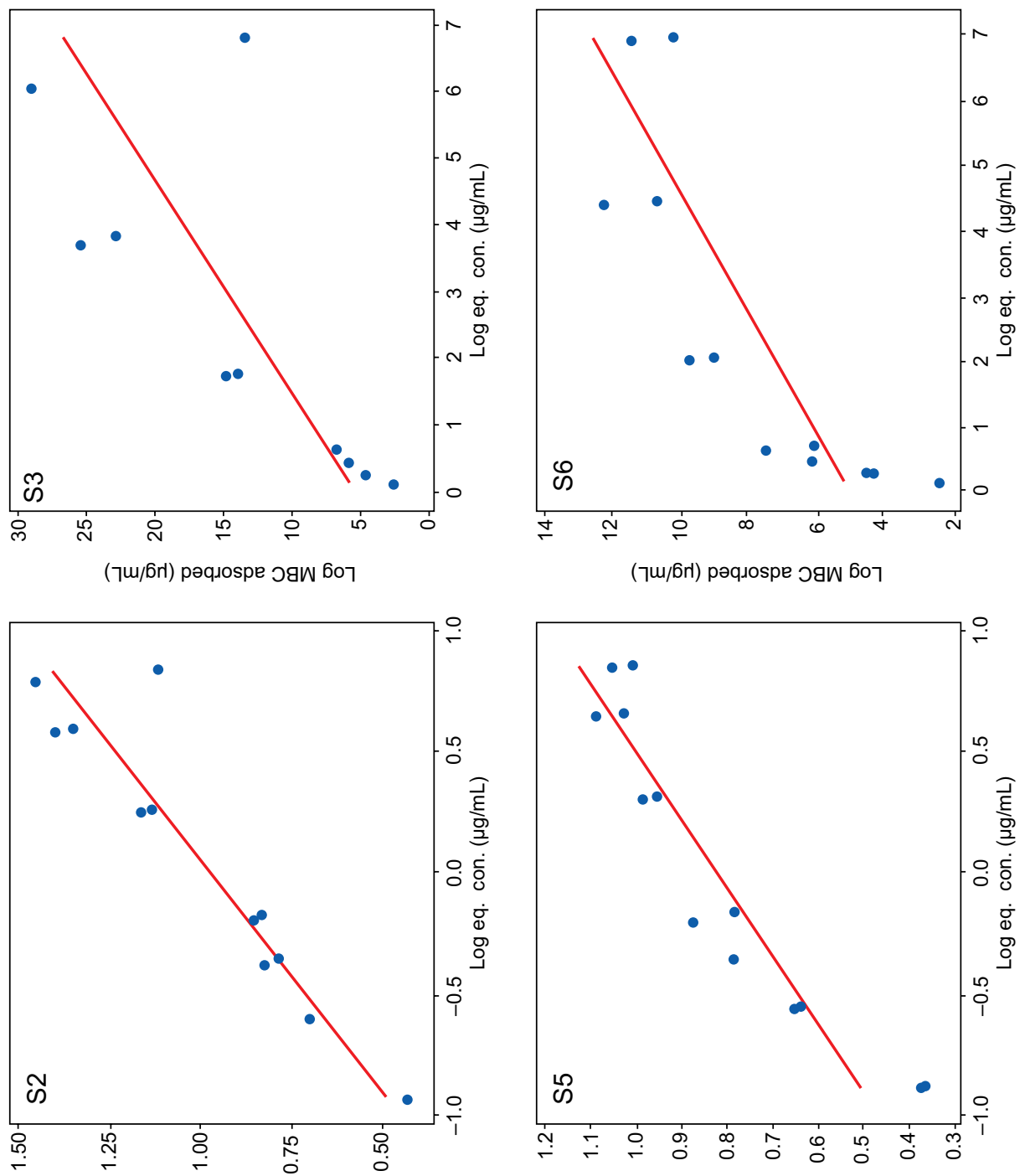

(ךm/бr) pәquospe Јaw боา
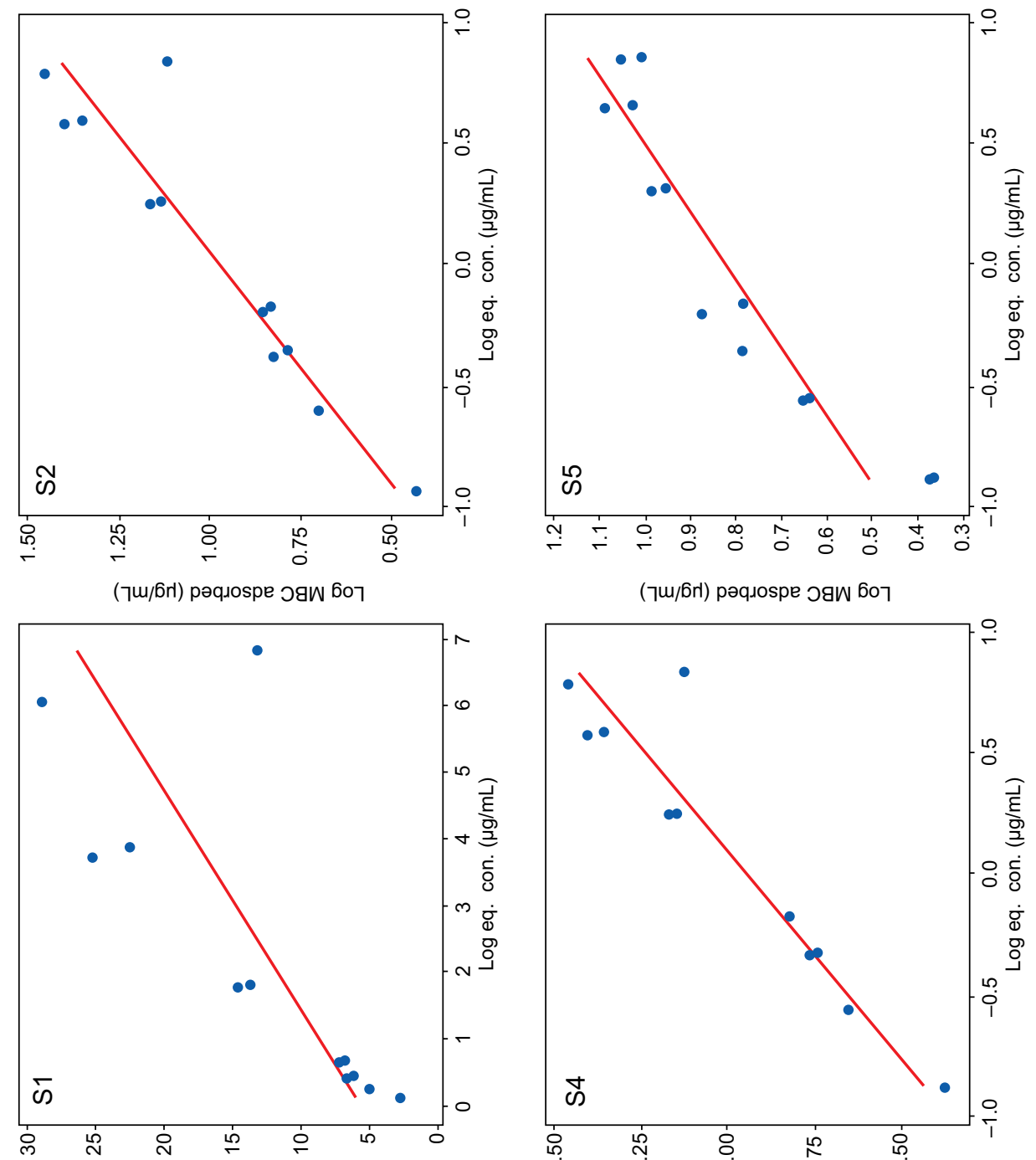

(ךm/6r) pәquospe Јaw боา

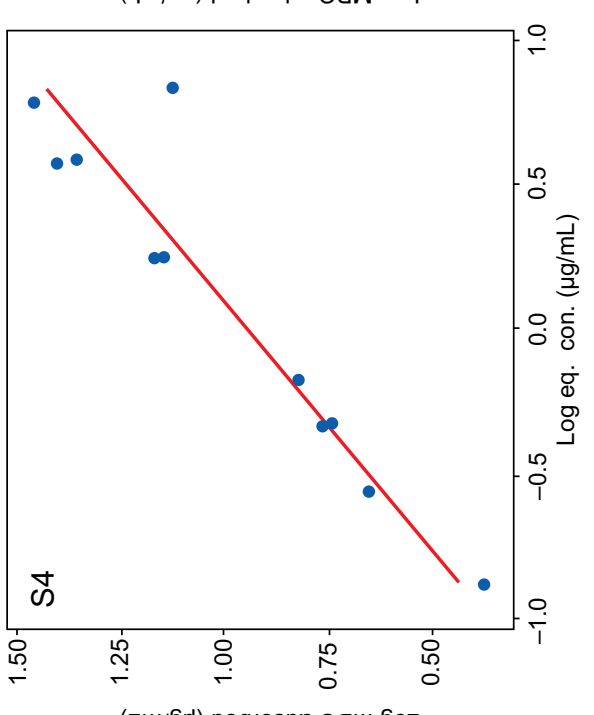

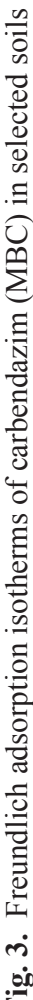

(ךu/6r) pәquospe วgw 60า

(ךm/6r) pәquospe วaw 6оך 
justified by the fact that the sand content in soil 2 is quite high, resulting in the process of desorption almost as quickly as adsorption.

\section{MBC soil transport}

$\mathrm{MBC}$ percolation to underground water bodies is an important factor for polluting the resources, which cannot be cleaned in a simple way. MBC percolation in soils can be determined from different techniques, e.g. thin layer chromatography (TLC) or regression analysis. As predicted by $K_{d}$ values showing difficult adsorption, the values for $\mathrm{K}_{\mathrm{oc}}$ are also suggestive of medium mobility of MBC to soil profiles and water bodies present underground in terms of McCall classification (McCall et al. 1980). This is suggestive of the fact that failure in timely remediation of MBC in the selected soils may result in contamination that is difficult to control later on. Particularly the absence of SOM and lower clay contents enhance this percolation. Current results are in conformity with the previously studied fungicides, e.g. tebuconazole (Vanclooster et al. 2000, Singh et al. 2016). Other investigations on hydrophobic fungicides are indicative of lower mobility patterns as in the case of pyraoxystrobin (Liu et al. 2018). In this regard, various researchers have also employed ground ubiquity score (GUS) and suggested that GUS $<1.8$ ensures minimum leaching (Wu et al. 2016). The current investigation of $\mathrm{MBC}$ adsorption in selected soils provides important information about its behavior in soils.

\section{MBC physiosorption}

$\mathrm{MBC}$ sorption in soil is determined via adsorption free energy $(\Delta G)$. Current results have given negative values for $\Delta G$ for $M B C$ adsorption into the soils, consistent with other fungicides, e.g. 14Cpyraoxystrobin (Liu et al. 2018) and strobilurin fungicides (Wu et al. 2016). A negative value of $\Delta \mathrm{G}$ for $\mathrm{MBC}$ adsorption shows that MBC molecules were not tightly bound to the interlayer of soils selected for adsorption, and that they were held together by temporary weaker bonds, e.g. hydrogen bonds, Van der Waal's forces etc. However, in case of strong adsorption, referred as chemisorption, MBC would have yield positive $\Delta G$ values. Such behavior of $\mathrm{MBC}$ is also suggestive of adsorptive interactions taking place only in the surface soils and that it has not invaded the deeper profiles (Liu et al. 2018). Negative values of $\Delta \mathrm{G}$ can be converted to positive values through organic amendment of selected soils, which will firmly held the MBC molecules (Sharma et al. 2015).

\section{Statistical analysis}

Statistical investigations were done regarding the relationship between $\mathrm{K}_{\mathrm{d}}$ and the physical and chemical properties of soil including OM, TOC and $\mathrm{pH}$. Linear regression analysis was performed to analyze the effect on $\mathrm{K}_{\mathrm{d}}$ of the physical and chemical properties (Fig. 4, Table VI). The analysis provided the knowledge that $\mathrm{pH}$ is negatively correlated to $\mathrm{K}_{\mathrm{d}}$, while OM and TOC were seen to be positively correlated. According to figure 4, the lowering $\mathrm{pH}$ enhances the adsorption of MBC in soils. In a nutshell, soil $\mathrm{pH}$ values are accountable for the dissociation or protonation processes of both, the MBC and the adsorbent surfaces of soils. Whereas, an increase in adsorption was observed with the increasing percentage of OM and TOC. The results also indicated that the soil 6 , having the highest $\mathrm{K}_{\mathrm{d}(\mathrm{ads})}$ value $(11 \mu \mathrm{g} / \mathrm{mL})$, contains the most percentage of soil OM (3.3\%), proving the fact that Soil OM is directly proportional to the rate of adsorption occurring in that particular soil. Also, the CEC value of 7.4 indicates that comparatively higher CEC values usually enhance adsorption, either by ion exchange or surface precipitation. One-way analysis of variance (ANOVA) was performed on the soil samples and their $\mathrm{K}_{d}$ values (Table VII). Different parameters of ANOVA included mean square (MS), P value (probability), degrees of freedom (df), sum of squares (SS), F statistics (F) and F critical values (F crit). The $\mathrm{P}$ value (0.9) was found to be greater than the alpha value $(\alpha)(0.05)$. The $F$ crit value was found to be 3.0 and the F statistics value was lower than it $(0.2)$. Value of $F$ statistics less than the F crit value proves that the experimental values are accurate and in an acceptable range. Furthermore, residual plots

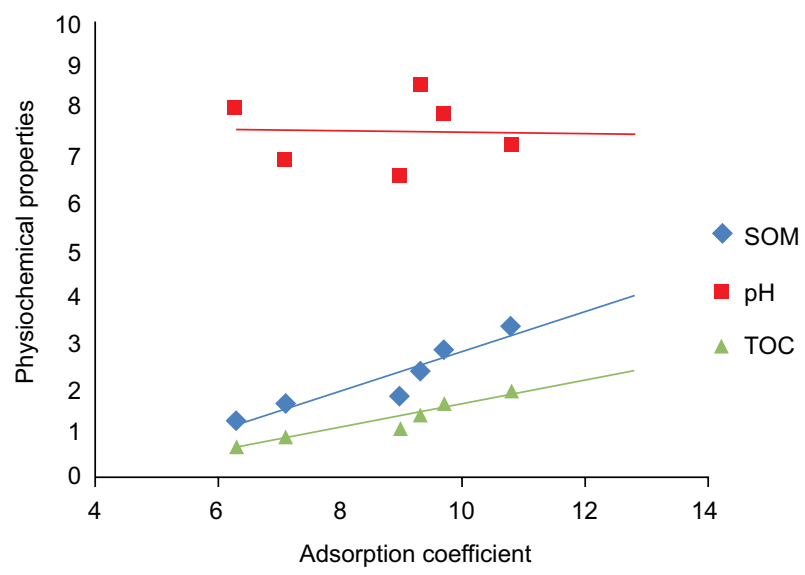

Fig. 4. Comparative graph expressing the relationship between $\mathrm{K}_{\mathrm{d}}$ and selected soils' physical and chemical properties 
TABLE VI. REGRESSION AND CORRELATION ANALYSIS OF ADSORPTION CHARACTERISTICS WITH SOIL PROPERTIES

\begin{tabular}{lccccc}
\hline $\begin{array}{l}\text { Sorption } \\
\text { coefficient }\end{array}$ & $\begin{array}{c}\text { Property } \\
(\mathrm{x})\end{array}$ & $\begin{array}{c}\text { Correlation } \\
\text { coefficient }(\mathrm{r})\end{array}$ & $\begin{array}{c}\text { Probability } \\
\text { level }(\mathrm{p})\end{array}$ & $\begin{array}{c}\text { Intercept } \\
(\mathrm{a})\end{array}$ & $\begin{array}{c}\text { Slope } \\
\text { (b) }\end{array}$ \\
\hline \multirow{3}{*}{$\mathrm{K}_{\mathrm{d}}$} & $\mathrm{pH}$ & -0.3 & 0.05 & 8.8 & -0.1 \\
& $\mathrm{SOM}$ & 0.9 & 0.06 & 1.3 & 0.6 \\
& TOC & 0.8 & 0.02 & -0.6 & 0.2 \\
\hline
\end{tabular}

$* \mathrm{~K}_{\mathrm{d}}=$ adsorption coefficient, $\mathrm{SOM}=$ organic matter, $\mathrm{TOC}=$ total organic carbon

TABLE VII. UNIVARIATE ANALYSIS OF VARIANCE ON SORPTION CHARACTERISTICS OF SOIL

\begin{tabular}{lcccccc}
\hline Source of variation & SS & df & MS & F & P-value & F crit \\
\hline Between soil samples & 10.0 & 5.0 & 2.0 & 0.2 & 0.05 & 3.0 \\
Within soil samples & 149 & 12 & 12 & & & \\
\hline
\end{tabular}

$\mathrm{MS}=$ mean square, $\mathrm{P}$ value $=$ probability, $\mathrm{df}=$ degrees of freedom, $\mathrm{SS}=$ sum of squares, $\mathrm{F}=\mathrm{F}$ statistics, $\mathrm{F}$ crit $=\mathrm{F}$ critical values. and normal probability plots were obtained in order to observe the goodness of fit of the experimental results (Fig. 5). Normal probability plots depict that the data is distributed normally while the residual plots display a constant variance of the data.

\section{$\mathrm{PD}-\mathrm{AC}$ triggered $\mathrm{MBC}$ removal}

$\mathrm{PD}-\mathrm{AC}$ was used for the remediation of the $\mathrm{MBC}$ contaminated soils in three different concentrations $(2.5,5.0$, and $7.5 \mathrm{ppm})$ of MBC. Solutions having
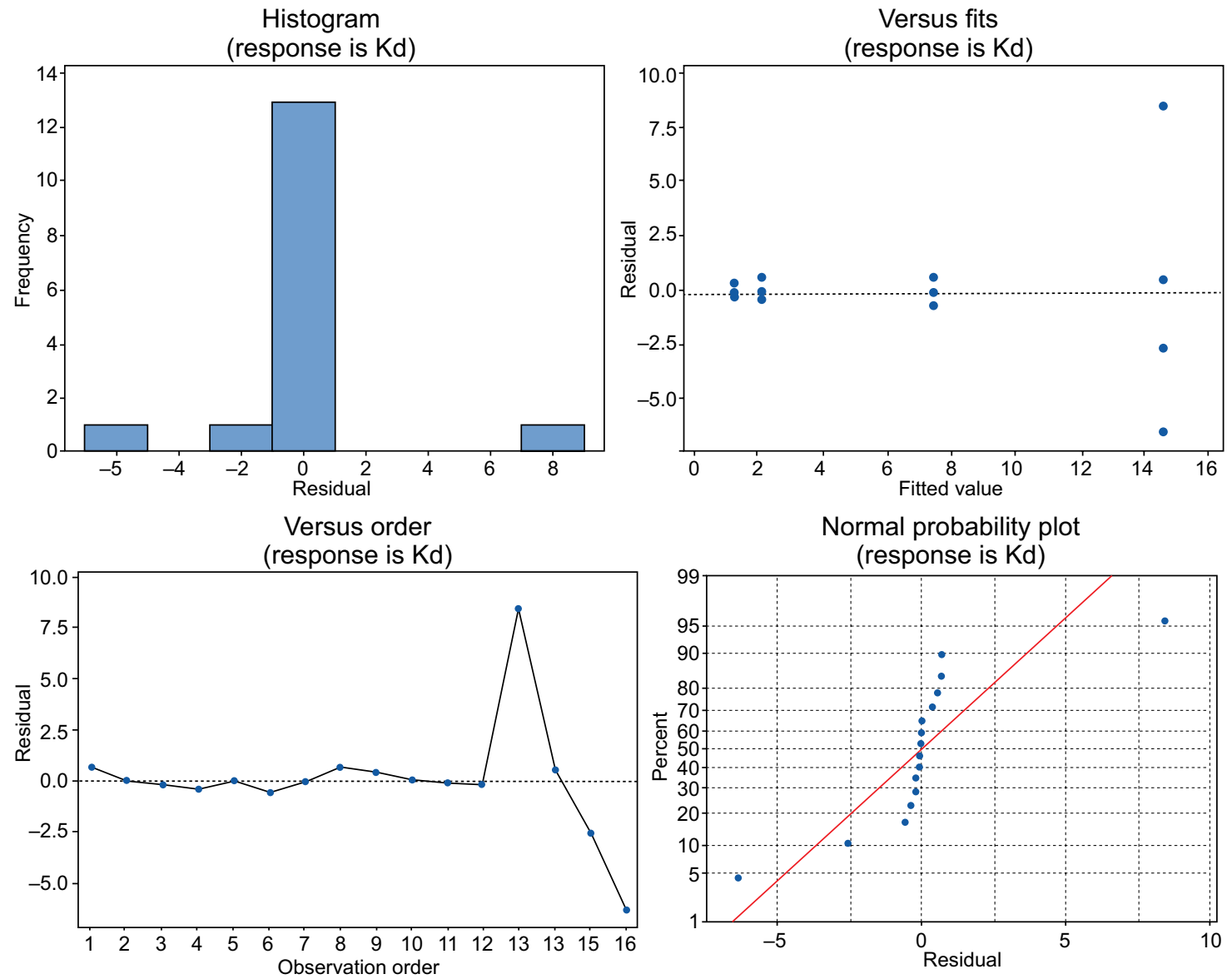

Fig. 5. Residual plots analysis of variance of soil samples with physical and chemical properties $\mathrm{pH}$, total organic carbon and organic matter, the response is adsorption coefficient $\mathrm{K}_{\mathrm{d}}$ 
TABLE VIII. REMOVAL OF MBC BY Prunus dulcis DERIVED ACTIVATED CARBONAT DIFFERENT CARBENDAZIM CONCENTRATIONS

\begin{tabular}{cccc}
\hline $\begin{array}{c}\text { Solution concentration } \\
(\mathrm{ppm})\end{array}$ & $\begin{array}{c}\text { UV absorbance before adding } \\
\text { activated carbon }\end{array}$ & $\begin{array}{c}\text { UV absorbance after addition of } \\
\text { activated carbon }\end{array}$ & $\begin{array}{c}\text { \% removal of pesticide } \\
\text { from solution }\end{array}$ \\
\hline 2.5 & 0.090 & 0.090 & 100 \\
5.0 & 0.324 & 0.115 & 36 \\
7.5 & 0.498 & 0.116 & 23 \\
\hline
\end{tabular}

$* \mathrm{UV}=$ ultraviolet

different initial concentrations $(2.5,5.0$, and 7.5 $\mathrm{ppm}$ ) of pesticide were measured for the absorbance using a UV-Vis spectrophotometer. The standard plots were obtained with "absorbance versus initial concentrations" on MS Excel 2010 (Fig. 6). After approximately $3 \mathrm{~h}$, all of the MBC was removed by PD-AC from the $2.5 \mathrm{ppm}$ solution $(100 \%$;

Table VIII). While $36 \%$ removal was observed from 5 ppm solution and $23 \%$ removal from 7.5 ppm solution. It can be deduced from the obtained removal percentages that the amount of MBC removed from a solution by PD-AC depends highly upon the concentration of MBC used. This shows an inverse relation between MBC removal and concentration. The lower concentration of solution means there are lesser molecules of MBC in solution, hence the percentage of removal is high as it takes less time for those molecules to get adsorbed on the surface of the activated carbon. Consequentially, a declining trend in pesticide removal with increasing
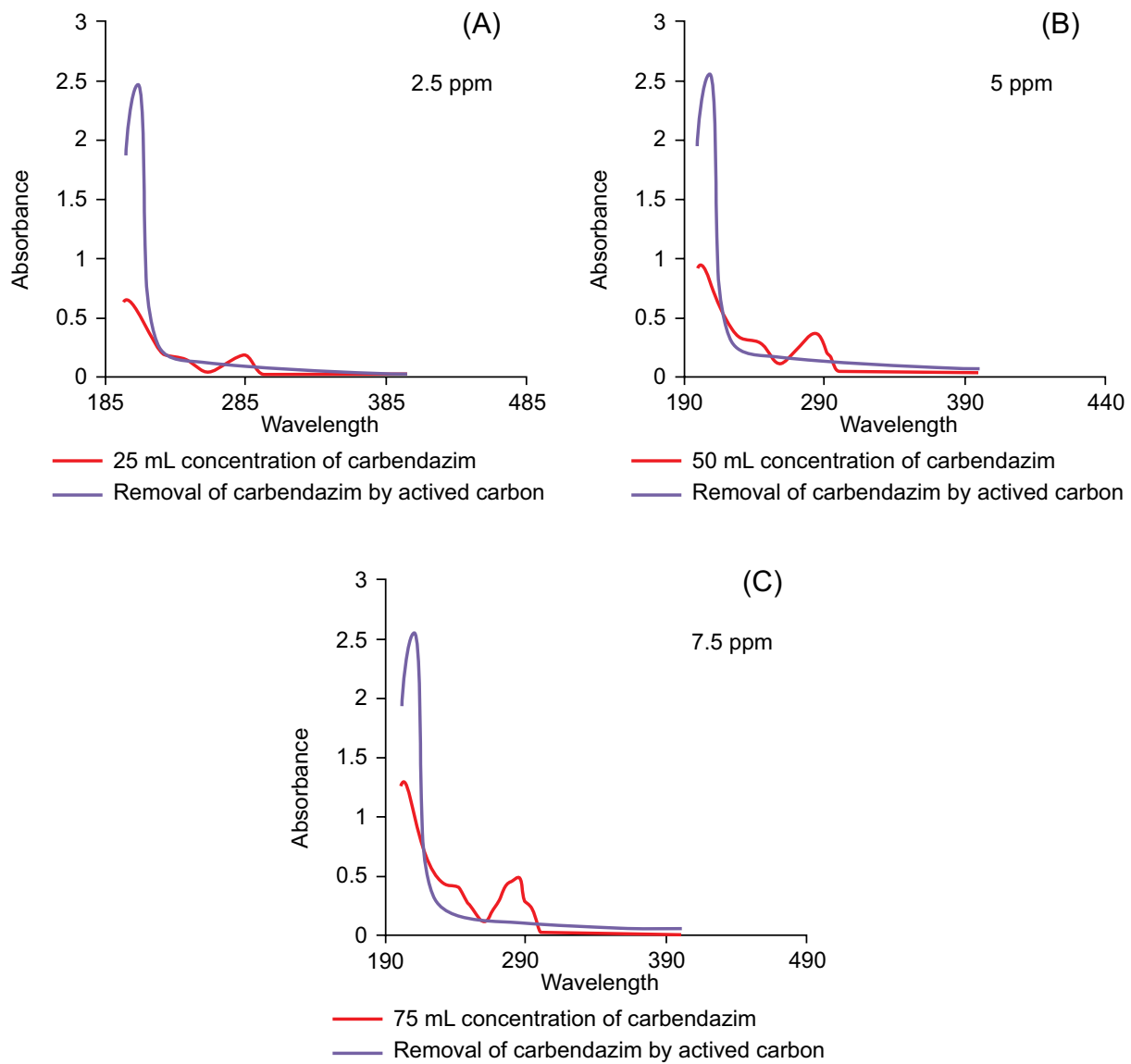

Fig. 6. Effect of Prunus dulcis derived activated carbon on different concentrations of carbendazim solutions (A) $2.5 \mathrm{ppm}$, (B) $5 \mathrm{ppm}$, (C) $7.5 \mathrm{ppm}$ 
concentration was observed. The use of PD-AC rendered this process to be environmentally friendly by using organic materials instead of hazardous chemicals. This process proved to be quite cost effective and economical also aiding in waste management by reusing wasted almond shells and requiring very low financial input while in turn providing a significant output.

\section{CONCLUSION}

Soils from various regions were investigated for their adsorption of MBC followed by removal by activated carbon prepared from dry almond shells. In all soils adsorption increased with the increasing concentration of the MBC. Soil sample 6 showed the highest adsorption because of highest organic matter and clay content. The research introduced the cost effective removal of carbendazim from soils using almond shells. The results indicate that activated carbon prepared indigenously was an attractive adsorbent for the removal of the pesticide. This implies that the same environmental friendly and cost effective way rather than chemical techniques for removal, can be utilized for different further pesticides as well.

\section{ACKNOWLEDGMENT}

The concept, idea, data and writing belong to author Dr. Khuram Shahzad Ahmad's Lab E-21. The author especially acknowledges Miss Gulistan Sher for assisting in experimental work during the completion of her BS degree.

\section{REFERENCES}

Ahmad K.S., Rashid N, Nazar M.F. and Tanzaiyan S. (2013). Adsorption and desorption characteristic of benzimidazole based fungicide carbendazim in Pakistani soils J. Chem. Soc. Pak. 34 (3), 1017-1024.

Ahmad K.S. (2017a). Determination of Rimsulfuron sorption parameters in eight Pakistani soils. Agrochimica. 61 (2), 140-153. DOI: 10.12871/0021857201714

Ahmad K.S. (2017b). Green electrokinetic remediation of Thiabendazole adsorbed soils via mineralization. Agrochimica. 61 (3), 190-205.

DOI: $10.12871 / 00021857201723$

Ahmad K.S. (2017c). Pedospheric sorption investigation of sulfonyl urea herbicide Triasulfuron via regression correlation analysis in selected soils. South Afr. J. Chem. 70 (1), 163-170. DOI: 10.17159/0379-4350/2017/v70a23
Ahmad K.S. (2018). Evaluating the adsorption potential of alachlor and its subsequent removal from soils via activated carbon. Soil Sed. Contam. Int. J. 27 (4), 249266. DOI: $10.1080 / 15320383.2018 .1470604$

Ali S., Ahmad M, Ali T, Shahbaz B, Khan G.A, Iftikhar M. and Nosheen F. (2013). Role of private sector in promoting IPM practices among farming community in Punjab, Pakistan. J. Anim. Plant Sci. 23, 1473-1476.

Arya R. and Sharma A.K. (2016). Bioremediation of carbendazim, a benzimidazole fungicide using Brevibacillus borstelensis and Streptomyces albogriseolus together. Curr. Pharm. Biotechnol. 17, 185-189.

DOI: $10.2174 / 1389201016666150930115737$

Azarkan S., Peña A, Draoui K. and Sainz-Diaz C.I. (2016). Adsorption of two fungicides on natural clays of Morocco. Appl. Clay Sci. 123, 37-46.

DOI: 10.1016/j.clay.2015.12.036

Boudina A., Emmelin C, Baaliouamer A, Grenier-Loustalot M.F. and Chovelon J.M. (2003). Photochemical behaviour of carbendazim in aqueous solution. Chemosphere 50 (5), 649-655.

Coupe R.H. and Capel P.D. (2015). Trends in pesticide use on soybean, corn and cotton since the introduction of major genetically modified crops in the United States. Pest Manag. Sci. 72, 1013.

DOI: 10.1016/S0045-6535(02)00620-3

de Oliveira Neto O.F., Arenas A.Y. and Fostier A.H. (2017). Sorption of thiabendazole in sub-tropical Brazilian soils. Environ. Sci. Pollut. Res. 24 (19), 16503-16512.

DOI: $10.1007 / \mathrm{s} 11356-017-9226-8$

Fenner K., Canonica S, Wackett L.P. and Elsner M. (2013). Evaluating pesticide degradation in the environment: blind spots and emerging opportunities Science, 341, 752-758. DOI: 10.1126/science. 1236281

Gul M.M. and Ahmad K.S. (2017). Chlorsulfuron degradation through bio-augmentation of soils by fungal strains and chemical hydrolysis. J. Environ. Chem. Eng. 6 (1), 955-963. DOI: 10.1016/j.jece.2017.12.016

Guo Y., Guo S, Li J, Wang E. and Dong S. (2011). Cyclodextrin-graphene hybrid nanosheets as enhanced sensing platform for ultrasensitive determination of carbendazim. Talanta. 84 (1), 60-64.

DOI: $10.1016 /$ j.talanta.2010.12.007

Herrero-Hernández E., Marín-Benito J.M, Andrades M.S, Sánchez-Martín M.J. and Rodríguez-Cruz M.S. (2015). Field versus laboratory experiments to evaluate the fate of azoxystrobin in an amended vineyard soil. J. Environ. Manag. 163, 78-86.

DOI: 10.1016/j.jenvman.2015.08.010

Iftikhar S., Ahmad K.S. and Gul M.M. (2018). Low-cost and environmental-friendly Triticum aestivum-derived 
biochar for improving plant growth and soil fertility. Comm. Soil Sci. Plant Anal. 49 (22), 2814-2827.

DOI: $10.1080 / 00103624.2018 .1546869$

Liu X., Wu H, Hu T, Chen X. and Ding X. (2018). Adsorption and leaching of novel fungicide pyraoxystrobin on soils by $14 \mathrm{C}$ tracing method. Environ. Monit. Assess. 190 (2), 86. DOI: 10.1007/s10661-017-6458-5

McCall P.J., Laskowski D.A., Swann R.L. and Dishburger H.J. (1980). Measurements of sorption coefficients of organic chemicals and their use in environmental fate analysis. Proc. Assoc. Off. Anal. Chem. 94, 89-109.

Paszko T. (2014). Adsorption, degradation and mobility of carbendazim in profiles of Polish mineral soils, Geoderma 226, 160-169.

DOI: 10.1016/j.geoderma.2014.02.007

Pose-Juan E., Sánchez-Martín M.J. and Andrades M.S. (2015). Pesticide residues in vineyard soils from Spain: Spatial and temporal distributions. Sci. Total Environ. 514, 351-358.

DOI: $10.1016 /$ j.scitotenv.2015.01.076

Roy N.K. (2002). Chemistry of pesticides. CBS Publishers and Distributors, New Delhi, India, 346 pp.

Salunkhe V.P., Sawant I.S, Banerjee K, Wadkar Pallavi N, Sawant S.D. and Hingmire S.A. (2014). Kinetics of degradation of carbendazim by B. subtilis strains: possibility of in situ detoxification. Environ. Monit. Assess. 186, 8599-8610.

DOI: $10.1007 / \mathrm{s} 10661-014-4027-8$
Sharma D.K., Verma N.K, Suman S. and Kashyap R.K. (2015). Pulse polarographic determination of thiophanate methyl fungicide in relation to its soil adsorption study. J. Anal. Sci. Technol. 6 (1), 13. DOI: $10.1186 / \mathrm{s} 40543-015-0051-8$

Silva R.C., Barros K.A. and Pavão. (2014). Carcinogenicity of carbendazim and its metabolites. New Chem. 37 (8), 1329-1334. DOI: 10.5935/0100-4042.20140214

Singh B., Farenhorst A, McQueen R. and Malley D.F. (2016). Near-Infrared Spectroscopy as a Tool for Generating Sorption Input Parameters for Pesticide Fate Modeling. Soil Sci Soc Am J. 80 (3), 604-612. DOI: $10.2136 /$ sssaj2015.03.0118

USEPA (2008) OPPTS 835.1230. Fate, transport and transformation test guidelines: Adsorption/desorption (batch equilibrium). EPA 712-C-08-009. Manual. United States Environmental Protection Agency. Washington, DC, USA, 53 pp.

Vanclooster M., Boesten J.J.T.I, Trevisan M, Brown, C.D. Brown, Capri E, Eklo O.M, Gotteesburen B, Guoy V. and Vander-Linden A.M.A. (2000). A European test of pesticide-leaching models: Methodology and major recommendations. Agri. Water Manag. 44 (1-3), 1-19. DOI: 10.1016/S0378-3774(99)00081-5

Wu P, Wu W.Z, Han Z.H. and Yang H. (2016). Desorption and mobilization of three strobilurin fungicides in three types of soil. Environ. Monit. Assess. 188 (6), 363. DOI: 10.1007/s10661-016-5372-6 